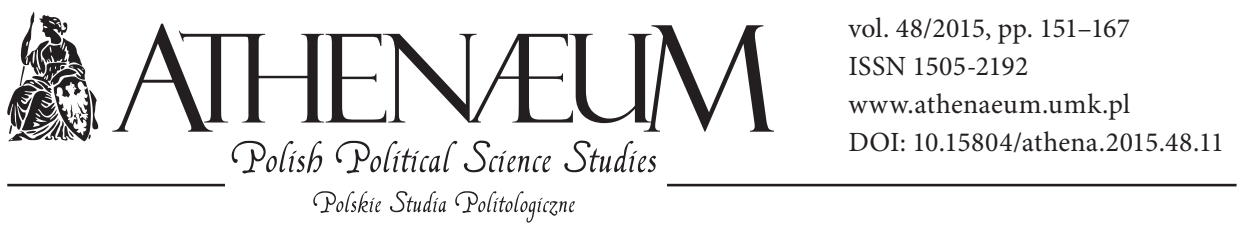

\title{
EFFICIENCY OF THE EU SOFT INSTRUMENTS IN THE TRANSFORMATION OF EASTERN NEIGHBOURS THE CASE OF THE UKRAINIAN CRISIS
}

Beata Piskorska*

\begin{abstract}
The subject of analysis is the assumption that the concept of soft power may be used as a theoretical basis for the interpretation of the EU influence on the less stable regions facing the spread of international conflicts. On the basis of current events and the high degree of instability in the region, it should be stated that such instruments are not efficient when it comes to Russia. In order to prove the above mentioned assumption, one needs to define the nature and specificity of the EU as soft power in the post-Westphalian international order. In the context of the use of such instruments, the analysis will also cover the manifestation of their implementation and efficiency in the EU policy towards Ukrainian crisis.

Thus, it is essential to answer a few research questions. Firstly, what is the specificity of the EU in post-Westphalian international order? Secondly, what means does the EU have at its disposal and is it able to achieve its objectives and meet expectations which the international environment has towards it? Lastly, how can we assess the efficiency of the soft power instruments used by the Union in specific region of Eastern Europe, particularly during Ukrainian crisis?
\end{abstract}

\section{- KEYWORDS}

the European Union, soft power, Ukraine, eastern neighbours, Eastern Partnership, crisis on Ukraine

* John Paul II Catholic University of Lublin, Institute of Political Science and International Affairs. 
The European Union in $21^{\text {st }}$ century wishes to play a global role adequate to its political, economic and diplomatic potential of 28 member states on the international arena. Thus, the European Union needs appropriate instruments which will help it become "stabilizer" and "promoter" in the closest neighbourhood. One of such instruments is connected with its huge economic position. However, it has been weakened by economic crisis. Others refer to its foreign policy which since its early days has been playing less significant role (Piskorska 2012: 108-109). Additionally, the EU political position, for over 60 years since its formation, has been affected by the lack of military dimension (hard power) when it comes to the integration process, and by the prolonged lack of Member states' consent concerning the EU shape in the context of hard power. The EU has never aimed at using military solutions based on a traditional understanding of power in the realization of its own foreign policy. One of the main objectives being set out now is the spread of the area of political and economic stabilization, promotion of democracy, particularly in the neighbouring regions by means of the instruments of so-called soft diplomacy.

One of the most dynamic areas of the EU interest, the one that stability and safety of the whole continent relies on, is the region of its direct neighbourhood - Eastern Europe. It was already noticed in the European Security Strategy accepted on December $12^{\text {th }}, 2003$, on the eve of the greatest enlargement, that changed the vision of a peacefully united continent (Council of the European Union, European Security Strategy, 2003). It contains a statement that "integration of accessing states increases safety but at the same time the EU is closer to the restless regions [...]. The EU task is to promote the formation of the ring of well-governed states to the east of the EU and alongside the coast of the Mediterranean and the EU may be linked to those states by the relations based on cooperation" (Council of the European Union, European Security Strategy, 2003). The EU objective in relation to its eastern neighbours focuses on the benefits resulting from economic and political cooperation as well as solving political problems there. Similar objectives were reinforced in 2008 in the presented Report on the implementation of the European Security Strategy (Council of the European Union, European Security Strategy, 2008). It was confirmed that Europe has safety interests outside its direct neighbourhood. The proof of this was Eastern Partnership established in 2008, which assumed the change in relationships with the EU eastern neighbours ${ }^{1}$.

\footnotetext{
1 The aim of the Eastern Partnership is to reinforce well-being and stability in these states and
} 
Recently in the area of Eastern Europe one can notice the regress connected with sharing common European political, economic and moral values. Transformations in Ukraine, the annexation of Crimea by Russia and implementation of the project of Euroasian Customs Union are of crucial importance for the whole EU. However, the most significant problem that the EU faced in 2014 was the Ukrainian crisis. Since the fall of 2013 the Russian and Ukrainian conflict has forced the Member states to accept a common position on the issue of stabilization of the Ukrainian problem.

The subject of analysis is the assumption that the concept of soft power may be used as a theoretical basis for the interpretation of the EU influence on the less stable regions facing the spread of international conflicts. On the basis of current events and the high degree of instability in the region, it should be stated that such instruments are not efficient when it comes to Russia. In order to prove the above mentioned assumption, one needs to define the nature and specificity of the EU as soft power in the post-Westphalian international order. In the context of the use of such instruments, the analysis will also cover the manifestation of their implementation and efficiency in the EU policy towards the Ukrainian crisis.

Thus, it is essential to answer a few research questions. Firstly, what is the specificity of the EU in post-Westphalian international order? Secondly, what means does the EU have at its disposal and is it able to achieve its objectives and meet expectations which the international environment has towards it ${ }^{2}$ ? Lastly, how can we assess the efficiency of the soft power instruments used by the Union in specific region of Eastern Europe, particularly during Ukrainian crisis?

the EU security at the same time. Proposal was developed before the broad range of fields of bilateral and multi-lateral cooperation including energetic safety and mobility of citizens.

${ }^{2}$ In the implementation of the EU foreign policy soft measures dominate, such as diplomatic actions, economic cooperation, encouragement or the use of the media. But at the same time, there are also instruments present which express the EU lack of acceptance for international patterns of behaviour, which violate the law such as Russia's policy towards Eastern Ukraine. 


\section{SPECIFICITY OF THE EU SOFT POWER IN THE POST-WESTPHALIAN} INTERNATIONAL ORDER

Defining the EU political potential has been the source of international relationships researchers' interest since the moment of union's establishment. One of the criteria of its perception is connected with its values and ideals. That is why the EU was most frequently viewed as a civilian power (Duchêne 1973; Telò 2007: 58-64), soft power (Hill 2010), normative, and even prudent and silent power (Manners 2002: 242-243), smart power (Nye 2011) ${ }^{3}$, ethical power (Aggestam), post-modernist superpower (McCormick), silent mediator (Nicolaïdis), mild power (Merlini 2002: 19-30), or a small one (Toje 2011: 43-60) ${ }^{4}$, neo-medieval empire (Zielonka). U. Beck described it as a peaceful empire. In the European languages, the term power appears as: German 'macht', French 'puissance', Russian 'derzhava', Spanish 'poder' (Tocci 2008: 3).

Apart from traditional conceptualization of the Union in the past within the confines of a narrow interpretation of military power $v s$ civilian one, numerous authors assign the EU with the adjective "soft" as its strong attribute in the world's politics, treating it as a unique model of "civilizing" international relationships without the need to use force. The concept of the EU as a civilian power put forward by F. Duchêne refers back to the ability to affect the international system, to propose its own model of stability and security with the use of political and economic means instead of military power (Duchêne 1973: 1-21). H. Sjursen (Sjursen 2006: 170) treats the EU as a power built on normative bases described as civilizing or civilzation power, which means that it is not so much a civilian power (in the sense of the lack of hard instruments at its disposal), but also normative, civilizing and ethical power in the international system. As a so-called small power, the EU tries to avoid confrontational behaviour, instead preferring promotion of diplomatic actions, values and exerting influence thanks to its cultural attractiveness. Moreover, its objective is to carry out mediations with third parties, encourage international law and introduce regulations in

\footnotetext{
${ }^{3}$ Smart power is defined as effective combination of both hard and soft power, according to J.S. Nye it was a clever, prudent and witty power.

4 Term 'small power' created by R. Keohane in the area of international relationships describes the space between small states and huge powers. According to him, the EU may be rather compared to other small powers such as Sweden or Argentina, rather than great powers such as China or Russia.
} 
environmental issues, fighting terrorism and non-proliferation of weapons of mass destruction (Toje 2011: 54).

The elements of the EU soft power may be also observed in the category of normative power. This term was developed and further clarified in the literature of the subject by I. Manners. He treated the EU as an actor of foreign policy aiming at shaping, initiating and spreading - in other words - normalizing principles and values in the international relations without the use of coercive measures (Manners 2002: 240). He thought that the EU refers to the five basic norms written down in the Union treaties such as: peace, freedom, democracy, rule of law, and human rights (Piskorska 2013: 6-10). He supplemented them with additional four norms of slightly lesser significance: social solidarity, lack of discrimination, permanent development, and good governance. Similarily, in the opinion of French political scientist Z. Laïdi, the Union is a normative power because it aims at "building world's order based on law-binding principles which may undergo re-negotiation or predictibility of behaviours" (Laïdi 2008: 4). In other words, the Union assumes management over sovereignity, influence over power, multilateralism over a state, law over force, and attraction over compulsion (Gnesoto 2012: 99-100). The Union is a leader of creation of new principles of universal importance. One of the examples may be the Kyoto Protocol on the climate changes and the International Court of Justice. R. Cooper pointed to the term "post-modernist Europe", describing it as an actor rejecting force as a means to solve internal problems, giving preferrence to integration over confrontation in politics, negotiations over conflict, and convenience of purposefulness and attractiveness of its attributes in the international environment (Gnesoto 2012: 100).

Following this line of thought, it shall be noticed that the EU, thanks to its power of attraction, is an influential political and economic actor mobilizing external states, especially neighbouring ones, to introduce desirable democratic and economic reforms (Young 2010: 1-13). This influence and its legitimization may be measured by the number of official documents signed by the EU and third states within confines of implemented foreign policy, that is the Partnership and Cooperation Agreements, Association Agreements, Deep and Comprehensive Free Trade Agreements, bilateral Action Plans under the European Neighbourhood Policy, and other political instruments created under Eastern Partnership. The EU objective which can be found in all these documents is to strengthen relations with neighbours on the basis of common values such 
as democracy, respecting human rights, rule of law, but also establishing the Charter of Fundamental Rights under the EU.

Following R. Kagan's argumentation, normative image of the EU in international relationships stems just from the weakness of the EU military abilities (Kagan 2002). According to Ch. Hill, it is only when these two terms are put together that they become the closest to the concept of soft power by J. Nye (Hill 2010: 183-184). As it was emphasized by R. Kagan, the EU normative power results from its perception as a peaceful and non-military actor - "the island of peace" especially towards its neighbours.

Regardless of the differences in interpretation of the term 'soft power' in the context of the role of the EU in worldwide, it refers to the influence on international environment by means of political, diplomatic, legal, and economic instruments instead of hard power (Ociepka 2008, Mellisen 2005, 2007, 2011) 5 . In the latter case, the EU sources are de facto very limited (Sjursen 2006: 235).

Soft power is the term which lies somewhere between attractiveness of culture and politics, and convincing, seducing, automatic attraction of others to a given action by the method of providing arguments in order to voluntarily act together and challenge new obligations and laws. American researcher of international relationships, J. Nye is considered to be a founding father of the term 'soft power'. In early 1990s, in his book Bound to Lead: The Changing Nature of American Power, he initiated both scientific and political discourse relating to further specification of the phenomenon of power in the context of its soft nature (Nye 2004a, 2008). In connection with the current reneissance of the soft power concept among politicians and researchers, the author summarizes the above theory as opposed to "hard power - military and economic one" (Ociepka 2012: 130). It substantially differs from hard power, being the ability to use hard stimuli in the form of carrots and sticks in economy and military activities, which may make someone follow our demands (Parmar, Cox 2010: 1-3)6. Thus, it meant the exploitation of ideological and cultural potential of a given state on which its credibility and attractiveness is built. The EU attempts at basing the image of positive power in the global politics using its potential in conflict transformation through association agreements and other forms of partnership, on the condition

\footnotetext{
${ }^{5}$ Classic public diplomation of the US was informative activity using the tools of traditional and cultural diplomacy addressing foreigners.

6 According to Nye, both hard and soft power are crucial in fighting terrorism but "attractiveness is far less costy than compulsion..." Nye J.S. (2004a). Soft Power: The Means to Success in World Politics. New York.
} 
that its partners are willing to accept its model as soft power. Needless to say, it is worth pointing out that the EU more and more frequently turns to the use of the instruments reserved for both terms - soft and hard power, now referred to as 'smart power'.

\section{THE EUROPEAN UNION'S SOFT POWER INSTRUMENTS IN ITS FOREIGN POLICY}

The EU model as a soft power is to assist the efficient implementation of its foreign policy objectives, and above all, to create peaceful transformations in and outside Europe. According to Nye, shaping others' preferrences through the use of the force of attraction lies in attractiveness of political and cultural values, ideas and visions, especially these of universal nature (as opposed to those "parochial" ones) and foreign policy, managed in accordance with commonly accepted norms, traditions and values (Nye 2004b: 111). While assessing the efficiency of soft power instruments and attributes in the EU foreign policy especially towards a now unstable Eastern Europe, it is vital to have a closer look at the EU objectives and measures it wants to undertake to restore the stability.

Commonly accepted sources of the EU soft power now include: attractiveness of the multi-level EU institutions and internal policies in international environment, protecting citizens, human rights, willingness to reform governments and laws, public diplomacy, economic power including acting as a mediator and international donor, the fact of being the source of greatest foreign and humanitarian aid, promoting stability - engaging in operations of the Common European Safety and Defence Policy all over the world, the EU diplomacy - the European External Actiion Service being the biggest diplomatic service globally $^{7}$. The EU also attempts to encourage so-called young democracies in Eastern Europe, Central Asia and North Africa in the course of electoral revolutions in Ukraine, Georgia, Serbia, Egypt, and Tunisia (among others, it sends its observers, is a negotiating party to terminate a conflict or withdraw Russian troops from the occupied areas).

7 The EU diplomacy was reinforced in the Treaty of Lisbon through sanctioning of High Representative of the Union for Foreign Affairs \& Security (now HR is Federica Mogherini) and stable structures of cooperation. 
Although there is no clearly specified strategy - some sort of comprehensively strategic document in which so-called "soft" nature of this organization in the world would be characterized, it may be assumed that the European Security Strategy, accepted by the EU Council in December 2003, and especially its review executed in December 2008, points out to the numerous new areas in which the EU should increase its attempts with the use of slightly milder instruments engaging soft power. The proof of the most visible use of soft instruments in the EU foreign policy is the European Neighbourhood Policy sanctioned at the beginning of this century (Piskorska 2012: 125-129), and since 2008 the Eastern Partnership acting directly for the EU eastern neighbours. The objective of this policy is democratic governance based on the EU democratizing potential, Europeanization, so-called normative pressure and social learning, more profound economic and transboundary cooperation ${ }^{8}$, and stabilization and safety of neighbouring states. However, the latest events in Ukraine have revealed that all these instruments have become inefficient to fully realize the EU objectives in the soft power realm? .

One of the EU soft power instruments is the program of Eastern Partnership initiated in 2008 by Poland and Sweden, following the five-day war between Russia and Georgia. It assumed the EU signing of association agreements and deep and comprehensive free trade agreements with Ukraine, Georgia, and Moldova. Since its start, the project was perceived by Russia as an open attack on its influence zone, especially that it did not exlude the entering of these states into the NATO zone. The vision of those states coming closer to the EU clashed with political (and in the case of Georgia and Ukraine, also military) Russia's opposition. It may be said that the progressively aggressive Russian politics in the region has weakened the importance of the European soft power, changing the system of power inside the Partnership states. Ukraine lost Crimea and was involved by Russia in the state of open war, Georgia has not been able to win back Abkhazia and South Ossetia (now under Russian control and occupation), Armenia was forced by Russia to choose the integration under the Eurasian

8 The aim of economic cooperation is the access to common market or other commercial benefits (e.g. connected with the process of obtaining a partnership in WTO; DCFTA with EP states).

9 The Ukrainian crisis, which began with the government's rejection of signing the association agreement just before the $3^{\text {rd }}$ Summit of Eastern Partnership in Vilnus on November $28-29^{\text {th }}, 2013$, resulted in a series of disastrous events. It started with peace demonstrations of pro-European integration students in the Independence Square in Kiev (since that moment known as Euromaidan) suppressed by the then government under leadership of ex-president of Ukraine, W. Janukowycz. 
Customs Union. Azerbaijan manouvers between Russia and the West but it clearly favours Russia as its priority (which was proven by weapon spendings equal over 5 billion US dollars). Moldova has become really sensitive to Russian pressures due to the situation in the Transnistria and Belarus has never given a sign to treat the Eastern Partnership as a real alternative. Having analyzed the current situation, it becomes clear that current political program requires verification (Bonikowska, Szczygielski 2014: 3).

In the context of the situation in Ukraine, the states of Eastern Partnership will not be able to deepen pro-European course of transformations ${ }^{10}$. Russia maintains efficient instruments of influence in the form of possible reinforcing its military presence in Transnistria and in this way exerting pressure on both Moldova and Ukraine; gas pressure (after initiation of the supplies of "blue fuel" from Romania, Russia still covers about $80 \%$ of the demand for gas in Moldova), or blockades of around 20,000 workers' arrival. Additional ban on the import of some food products and threats of terminating contracts of free trade with Russia constitute a serious setback for the economy of the Eastern Partnership states.

What does that mean for the implementation of the EU's soft instruments within the Eastern Partnership, particularly before the forthcoming $4^{\text {th }}$ summit of the Eastern Partnership in Riga? Will we face the comeback instruments of force in the implementation of security policy on the international arena in connection with Russia's hard politics? It turns out that the European states still represent various interests and not all of them treat the Ukrainian problem as a priority, especially that the southern borders of the continent also face considerable instability. In the nearest future, we can expect further tightening of negative instruments by the Union and the USA - economic sanctions towards Russia. The Ukrainian crisis has wider consequences for international policy. The course and character of this conflict prove that patterns and rules of the current international orders waver.

10 Belarus may be slightly open to the relations with the EU (partly due to the EU-Ukraine Customs Union in Minsk and breaking of the diplomatic impass in the contact with the West), but this will be another attempt to gain partial independence from Russia rather than actual modification of the course. Azerbaijan and Armenia are still too tightly related to Russia in the field of safety to tighten political relationships with the West (the issue of Russian weapon supplies and Kremlin's guarantees to sustain status quo in Nagorno-Karabakh). Georgia, already associated with the EU, will soon face the increased military pressure of Russia in Southern Abkhazia and South Ossetia because Russia has announced the formation of a new military alliance with separatist republics. It is also difficult to expect a brand new change for plus in Moldova. 
Almost 6 years after the formation of the Eastern Partnerhip in 2008, now there is a necessity of its redefinition because of the challenges it faces, and above all, Russia's attempts to change the geopolitical map in the area, which in Russia's opinion, belongs to its zone of influence. Russia perceives the EU policy towards the common neighbourhood as a game of zero sum for its geopolitical dominance. That is why Russia uses measures the aim of which is to punish the ambition of the Eastern Partnership states to come closer to the EU and by means of violence Russia puts forward its own offer of entering the Euroasian Economic Union.

\section{EFFICIENCY OF THE SOFT POWER INSTRUMENTS USED BY THE UNION DURING UKRAINIAN CRISIS}

Starting with political instruments, Europeanization of the Eastern Partnership states is essential from the point of view of phenomena taking place in the EU neighbourhood. In spite of the strong imperial tendencies of Russia, Ukraine, Moldova, and Georgia still seek closer relations with the EU ${ }^{11}$. The first political part of the association agreement with Ukraine was initialled in March 2012 and signed 2 years later in March 2014. Ratification by the EU Parliament and Ukrainian Parliament took place on September $16^{\text {th }}, 2014$, and the agreement entered into force on November $1^{\text {st }}, 2014^{12}$.

Signing the economic part of the association agreement (DCFTA) on June $26^{\text {th }}, 2014$ encountered certain difficulties. As a result of Russian influence on the dialogue between Ukraine and the EU concerning the agreement, the ratification was put off till December $31^{\text {st }}, 2015$, after the ratification by 28 parliaments of the MSs. DCFTA may become effective as the whole or partially in the temporary mode in 2-4 years after obtaining the consent of the Parliament and the unanimous EU Council decision (Merabishvili 2014: 1). DFCTA means removing duties for $95 \%$ of goods imported from Ukraine and sustaining export duties to Ukraine ${ }^{13}$.

11 Moldova and Georgia initialled association agreements at the summit of the Eastern Partnership in Vilnus in November 2013.

12 In December 2014, President B. Komorowski signed the act on ratification of association agreement between Ukraine and the European Union.

13 'In the run-up to the Eastern Partnership's Vilnius Summit in 2013, Russia's leadership argued vociferously that the EU-Ukraine Deep and Comprehensive Free Trade Agreement (DCFTA) would 
As far as security matters are concerned, the EU does not participate in solving conflicts in the eastern states (including Ukraine) by means of military instruments. Several times it acted as a mediator and advisor. This situation has changed with the spread of the EU and formation of the European Security and Defence Policy. The EU interests in the neighbourhood were defined in the Union documents, among which there are forecasts of "fighting terrorism and weapons of mass destruction with respecting the international law of solving conflicts" (Council of the European Union: 2003). The test for the efficiency of the EU military instruments was the Russian and Georgian war in 2008. The Union succeeded in reaching the agreement but eventually it was not able to execute it. The Ukrainian crisis thus affects the need to work out a new, realistic safety strategy for the EU. In 2012, the decisions were made to prepare a new strategy till June 2015.

Additionally, the conflict in Ukraine revealed the crisis of the EU's idea that is a fundament of the EU, without which it cannot become a reliable global actor. The EU tries to adapt to new conditions of safety in Eastern Europe and perform actions promoting stabilization of Eastern Ukraine basically by means of soft instruments such as consultation and negotiations. On July $22^{\text {nd }}, 2014$, the EU sent to Ukraine a special monitoring (civilian) mission on behalf of CSDP. Kálmán Mizsei became its leader on June $24^{\text {th }}, 2014$. Unfortunately, he did not take part in diplomatic negotiation aiming at the termination of the conflict in Minsk in February 2015. The leaders of France, Germany, Ukraine, and Russia became the negotiating parties.

The above episode is the evidence of inconsistence and lack of unanimity of the EU member states towards eastern neighbours. Unfortunately, it shall be stated that the EU member states do not express a uniform opinion when it comes to Russia and they mostly rely on the realization of their own interests, mainly economic ones. The European Union has entered into a geopolitical

damage both Russia's economy and trade between Russia and Ukraine. The governments of Vladimir Putin and Viktor Yanukovych insisted on setting up a trilateral mechanism, which would include the European Union, to address these concerns and to re-negotiate the EU-Ukraine agreement. The European Commission did not agree to re-negotiate an already negotiated bilateral EU-Ukraine agreement in a trilateral format, especially given the objections of the third party. Instead, the Commission preferred to discuss the Russia's concerns directly with Russia. Despite its initial reluctance, the European Commission did agree to start trilateral talks regarding the EU-Ukraine DCFTA in July 2014, in parallel with the gas negotiations that began earlier'. See: G. Merabishvili, Triangular Geopolitics in Europe's Eastern Neighbourhood, http://www.ceps.eu/system/files/CEPS\%20Commentary\%20GM\%20Triangular\%20Geopolitics.pdf . 
struggle with Russia without having at its disposal - or even desiring to have the corresponding military force (which was Russia's trump card in Armenia's case) or mercantilistic power (which derailed Ukraine's Association Agreement) (Makarychev, Devyatkov 2014: 1-2). The EU's eagerness to strengthen its geopolitical muscle and challenge Russia in its so-called near abroad is a result of at least two related factors that suggest fragmentation within the EU rather than its consolidation. The first is the growing activism of Poland and Germany as co-shapers of the new political landscape in Eastern Europe. The second is the predominance of European, particularly German, economic lobbyists in the policymaking process (Makarychev, Devyatkov 2014: 2).

Sustaining the tension serves the West's belief that the crisis cannot be settled on their own terms. The EU itself lacks consequence towards Russia, which is proved by the lack of the EU states' consent to the degree of further sanctions laid upon it. The sanctions' results were not far-reaching and acute: they mainly struck single people and companies, the biggest players (such as Gazprom and Rosnieft) can easily "circumvent" restrictions thanks to advantageous contracts with Chinese subjects. Paradoxically, countersanctions laid upon Russia on the West are socially more severe, for example the ban on the import of Polish apples. This has led to the substantial reduction of the goods on the Russian market and, consequently, to the rise of prices of some products including food.

At the same time, the Union carries out activities aiming at rising Russian costs of exercising policy which violates the law through the use of both positive and negative economic instruments such as three degrees of economic, financial and visa sanctions, or termination of economic contracts. Moreover, it tries to support Ukraine financially paralell with the miliatry support of NATO actions (September $5^{\text {th }}$, NATO summit - support of the Eastern EU flank, so-called "spearhead", being ready early in 2015) ${ }^{14}$.

The EU attempts to build its soft power on the values, but as J.S. Nye warns, "political values such as democracy or human rights may be a strong source of attraction but it is not enough to only share them" (Nye: 2004). The European values strongly influence the conscience of EP societies but this aspect may become buried if the EU does not open to EP societies. It is necessary to clearly

14 A new "spearhead" force could be deployed within days to cope with emerging threats. This "spearhead" force, estimated at around 4,000 troops, is meant to be ready by 2016, but with eastern NATO allies nervous at Russian actions in Ukraine and Islamic State controlling large areas of Syria and Iraq, member states want something on the ground a lot faster. 
refer not only to the concept of "neighbourhood" but also to the united Europe in which the Union would create prospects for the states which are most advanced in internal reforms. The progress in negotiations concerning visa facilitations are the first step in this direction.

Moreover, the EU is the greatest donor of developmental and humanitarian aid all over the world, which also increases its soft power in relation to its eastern neighbourhood. In March 2011, the document entitled A New Responses to the Changing Neighbourhood. A Review of the European Neighbourhood Policy was accepted, in which the EU willingness to strengthen democracy and human rights in the regions of eastern and southern neighbourhood as well as increase in the transfer of aid measures through the organizations of civilian society is particularly visible.

In the years 2014-2020 the Committee plans to spend 83,2 billions EUR $(100 \%)$ on the instruments of external aid including developmental one (European Commission, 2014). It spends 15,7 mln EUR (19\%) on Pre-accession assistance (IPA); European Neighbourhood Instrument (ENI) - 21,9 mln EUR (26,3\%), Development Cooperation Instrument (DCI) - 23,4 mln EUR (28,1\%); Partnership Instrument (PI) - 1,1 mln EUR (1,4\%), European Instrument for Democracy and Human Rights (EIDHR) - 1,8 mln EUR (2,2\%); Instrument for Stability (IfS) - 3,1 mln EUR (3,8\%); Humanitarian Aid (HA) - 9,2 mln EUR (11,1\%); Common Foreign and Security Policy (CFSP) - 3,1 mln EUR (3,8\%); other actions and programmes - 3,5 mln EUR (4,3\%) (European Commission 2013: 21).

Table 1. Commitment appropriations in the area of external activities (EU budget 2014)

\begin{tabular}{|l|c|c|}
\hline Instrument & Mln EUR & \% \\
\hline European Neighbourhood Instrument (ENI) & 2192,2 & 26,3 \\
\hline Instrument for Pre-accession assistance (IPA) & 1578,4 & 19,0 \\
\hline Development Cooperation Instrument (DCI) & 2341,0 & 28,1 \\
\hline Partnership Instrument (PI) & 118,9 & 1,4 \\
\hline European Instrument for Democracy and Human Rights (EIDHR) & 184,2 & 2,2 \\
\hline Instrument for Stability (IfS) & 318,2 & 3,8 \\
\hline Humanitarian Aid (HA) & 920,3 & 11,1 \\
\hline Common Foreign and Security Policy (CFSP) & 314,5 & 3,8 \\
\hline
\end{tabular}


Table 1. cd

\begin{tabular}{|l|c|c|}
\hline Instrument & Mln EUR & \% \\
\hline $\begin{array}{l}\text { Other actions and programmes } \\
\text { (including decentralised and executive agencies) }\end{array}$ & 357,3 & 4,3 \\
\hline Total & 8325,0 & 100,0 \\
\hline
\end{tabular}

Source: European Commission 2013: 21.

However, it is emphasized that not only financial support is vital but also opening up to societies and putting emphasis on bottom-up democracy. It shall be also remembered that humanitarian and developmental aid is the "European alibi" which avoids greater engagement into connections of eastern states with Europe, which may be only realized in the prospect of supporting their reforms even at the cost of worsened relations with Russia. The basis is to create advantageous conditions for foreign investment of the European companies on eastern markets.

Summing up, it may be assumed that the EU carries out the policy based on the values and attractiveness, that is, on soft power. Russian Federation to a larger degree uses hard power in the post-Soviet area and by means of threat or money regulates the relations among the states exploiting "frozen" conflicts in the region. This provokes questions about the efficiency of foreign and safety policy of both subjects and the strategy of dealing with post-Soviet states as far as the regulation of military conflicts is concerned.

\section{CONCLUSIONS}

The analysis of the EU policy as soft power in the international environment has entered into the current discussion of the role and dynamics of the power in the global politics. It has revealed that the Union rejects hard instruments such as military power and bases its activities mainly on international law (international conventions) and actively promotes multilateral cooperation. The Union's mission to "civilize" international relationships is the evidence for the current spread of these ideals using political and economic benefits to transform other ones.

Thus, it shall be emphasized that the EU soft policy is the proof of occurence of new tendencies in the international relationships. Firstly, not only hard power but also soft power is (and will be) necessary and sufficient condition to become 
a superpower in the realm of international relationships. Secondly, soft power stems from and is based on respecting provisions of the international law, multilateralism and its promotion. Thirdly, the resources of the EU soft power are considerably greater than those of other subjects of international relationships as compared to the United States, because the codes of conduct and basic values shared by it are of bigger universal value.

However, because of the low efficiency of the realization of the EU role in the international environment, numerous experts claim that the concept of the EU as soft power is the effect of the weak EU foreign policy. It is to substitute other instruments of affection but also to mask its own infirmity. Because of this, the EU basing its activities solely on soft power becomes unable to act as a stabilizer and creator of the international order. And even if it uses such instruments, they work only for a short period of time. European values promoted by the EU are not enough supported by concrete actions which leads to low efficiency of declared objectives and the decrease of reliability of the EU policy towards international partners and legitimization of political support for its foreign policy. Moreover, it shall be stated that soft power is more and more often perceived as a reverse of power, which in the case of the EU rather constitutes a philosophy or long-term political strategy (the case of the European Neighbourhood Policy).

Due to rather blurred border between various kinds of the EU power in international relationships, quite convincing is the argumentation that the Union needs formulating a separate strategy of "soft power". There is no uniform strategy of the Union to use the instruments of foreign policy in the contemporary era of the civilization power.

\section{REFERENCES:}

A Budget for Europe (2014-2020). [online] http://europa.eu/legislation_summaries/ budget/bu0001_pl.htm; [accessed 15.12.2014].

Bonikowska M., Szczygielski M. (2014). Partnerstwo Wschodnie - potrzeba redefinicji. "Komentarze i Opinie" 4.

Council of the European Union (2003). A Secure Europe in a Better World - the European Safety Strategy, December 12 $2^{\text {th }}, 2003$. [online] http://www.consilium.europa. eu/uedocs/cms_data/librairie/PDF/QC7809568PLC.pdf; [accessed 29.09.2014].

Council of the European Union (2008). Report on the Implementation of the European Security Strategy - Providing Security in a Changing World - Brussels. 11 December 2008, S407/08. [online] http://www.consilium.europa.eu/ueDocs/cms_Data/docs/ pressdata/EN/reports/104630.pdf; [accessed 15.02.2015]. 
Duchêne F. (1973). The European Community and the Uncertainties of Interdependence. [in:] A Nation Write Large? Foreign-Policy Problems before the European Community. W. Hager, M. Kohnstamm (eds.). London.

European Commission 2013. Multiannual Financial Framework 2014-2020 and EU Budget 2014, the Figures.

Gnesoto N. (2012). Przyszłość Europy strategicznej. Warszawa: Polski Instytut Spraw Międzynarodowych.

Hill Ch. (2010). Cheques and Balances. The European Union's Soft Power Strategy. [in:] Soft Power and US Foreign Policy. Theoretical, Historical and Contemporary Perspectives. I. Parmar, M. Cox (eds.). New York.

"Journal of European Public Policy" (2006).

Kagan R. (2002). Power and Weakness. "Policy Review" 113.

Laïdi Z. (2008). Norms over Force: The Enigma of European Power, [w:] EU Foreign Policy in a Globalized World. Normative power and social preferences, Z. Laïdi (eds.). New York.

Makarychev A., Devyatkov A. (2014). The EU nn Eastern Europe: Has Normative Power Become Geopolitical?. "PONARS Eurasia Policy” Memo No. 310.

Manners I. (2002). Normative Power Europe: Contradiction in Terms?. "Journal of Common Market Studies" 40/2.

Mellisen J. (2005). Wielding Soft Power: The New Public Diplomacy. “Clingendael”, May, Issue 2.

Melissen J. (eds.). (2007). The New Public Diplomacy. Soft Power in International Relations. London.

Melissen J. (eds.). (2011). Public Diplomacy and Soft Power in East Asia (Global Public Diplomacy). London.

Merabishvili G. (2014). Triangular Geopolitics in Europe's Eastern Neighbourhood. "CEPS Commentary", December.

Merlini C. (2002). US Hegemony and the Roman Analogy: A European View. "International Spectator" 37, 3.

Nye J.S. (2004a). Soft Power: The Means to Success in World Politics. New York.

Nye J.S. (2004b). Soft Power and US Foreign Policy. "Political Science Quarterly" Vol. 119, No. 2. New York.

Nye J. S. (2008). The Powers to Lead. New York.

Nye J.S. (2011). The Future of Power. New York.

Ociepka B. (eds.). Dyplomacja publiczna (2008). Wrocław: Wydawnictwo Uniwersytetu Wrocławskiego.

Ociepka B. (2012). Nowa dyplomacja publiczna - perspektywa teorii stosunków międzynarodowych i komunikowania politycznego. "Przegląd Strategiczny" 1.

Parmar I., Cox M. (eds.). (2008). Soft Power and US Foreign Policy. Theoretical, Historical and Contemporary Perspectives. New York.

Piskorska B. (2012). Unia Europejska w poszukiwaniu nowej strategii w polityce światowej po Traktacie z Lizbony. [in:] Organizacje międzynarodowe wobec poli- 
tycznych i społecznych problemów świata. W. Gizicki (ed.). Toruń: Wydawnictwo Adam Marszałek.

Piskorska B. (2013). Wartości czy interesy? Europejska Polityka Sasiedztwa jako test na efektywność normatywnej siły UE w stosunkach międzynarodowych. "Analiza Natolińska" 11 (70).

Sjursen H. (2006). What Kind of Power?, "Journal of European Public Policy" 13/2.

Telò M. (eds.). Europe: A Civilian Power? European Union, Global Governance, World Order. (2007). London.

Tocci N. (2008). When and Why Does the EU Act as a Normative Power in Its Neighbourhood?. [in:] What Prospects for Normative Foreign Policy in a Multipolar World?. "ESF Working Paper" 29.

Toje A. (2011). The European Union as a Small Power. "Journal of Common Market Studies" 49/1.

Young R. (eds.). (2010).The European Union and Democracy Promotion. A Critical Global Assessment. Baltimore. 